\title{
Habitat Preferences, Distribution Pattern, and Root Weight Estimation of Pasak Bumi (Eurycoma longifolia Jack.)
}

\section{Siti Masitoh Kartikawati ${ }^{1 *}$, Ervizal Amir Muhammad Zuhud ${ }^{2}$, Agus Hikmat ${ }^{2}$, Hariadi Kartodihardjo ${ }^{3}$, Munawar Fuadi ${ }^{4}$}

\author{
${ }^{1}$ Graduate School of Bogor Agricultural University, Dramaga Main Road, Campus IPB Dramaga, Bogor, Indonesia 16680 \\ ${ }^{2}$ Department of Forest Resources Conservation and Eco-tourism, Faculty of Forestry IPB, Academic Ring Road, Campus IPB \\ Dramaga, Bogor, Indonesia 16680 \\ ${ }^{3}$ Department of Forest Management, Faculty of Forestry IPB, Academic Ring Road, Campus IPB Dramaga, PO Box 168, \\ Bogor, Indonesia 16680 \\ ${ }^{4}$ Faculty of Forestry, Tanjung Pura University, Imam Bonjol Street, Pontianak, Indonesia 78124
}

Received Februari 4, 2014/Accepted April 11, 2014

\begin{abstract}
Pasak bumi (Eurycoma longifolia Jack) is one of non timber forest products with "indeterminate" conservation status and commercially traded in West Kalimantan. The research objective was to determine the potential of pasak bumi root per hectare and its ecological condition under natural habitat. Root weight of E. longifolia Jack was estimated using simple linear regression and exponential equation with stem diameter and height as independent variables. The results showed that the individual number of the population was 114 with the majority in seedling stage with 71 individuals (62.28\%). The distribution was found in clumped pattern. Conditions of the habitat could be described as follows: daily average temperature of $25.6^{\circ} \mathrm{C}$, daily average relative humidity of $73.6 \%$, light intensity of $0.9 \mathrm{klx}$, and red-yellow podsolic soil with texture ranged from clay to sandy clay. The selected estimator model for E. longifolia Jack root weight used exponential equation with stem height as independent variable using the equation of $Y=21.99 T^{0,010}$ and determination coefficient of 0.97. After height variable was added, the potential of E. longifolia Jack minimum root weight that could be harvested per hectare was $0.33 \mathrm{~kg}$.
\end{abstract}

Keywords: Eurycoma longifolia, habitat preference, distribution pattern, root weight

*Correspondenceauthor,email:kartikawt@gmail.com,tel:+62-81280514144

\section{Introduction}

E. longifolia Jack. is one of non timber forest product that is commercially traded in in West Kalimantan. According to Rifai (1975). E. longifolia Jack. is generally found in shrub or tree forms with height that can reach $10 \mathrm{~m}$, odd pinnate compound leaves, yellow stem, hard tree bark and very bitter taste. Mardisiswojo and Harsono (1968) stated that E. longifolia Jack. is wild plant which mainly found in Sumatra and Kalimantan. All parts of the plant (root, stem, root bark, and leaf) are proved to be medicinal. Certain studies report that pharmacologically, E. longifolia Jack. contains anticancer compound (Nurhanan et al. 2005; Tee et al. 2007), anti-bacteria (Farouk \& Benafri 2007), osteoporosis therapy for men (Effendi et al. 2012), cyto-toxic (Kuo et al. 2003; Kuo et al. 2004), aphrodisiac (Ang et al. 2003; 2004), antileukemia, anti-malaria, and dysentery (Chan et al. 2005). Due to its various benefits, there has been a substantial increase in its demands for medicinal ingredients. The dry product is market at quite high price. According to the company data of UD Sumatra Pasak Bumi as the exporter of
E. longifolia Jack base in Deli Serdang, the export price for chipped root is USD249.16 kg-1. Meanwhile, the price for extracts 1:200 is USD3242.85 kg $\mathrm{kg}^{-1}$ and extracts 1: 50 with the price of USD1625 kg-1 . The price has increased compared to the price in 2012 of the extracts 1:50 with the price of USD375 $\mathrm{kg}^{-1}$ and for extract 1:200 with the price about USD900 kg ${ }^{-1}$ (Sumatra Pasak Bumi 2013). Such high price has encouraged the increase exploitation of E. longifolia Jack in the forest since current harvesting relies only on wild $E$. longifolia Jack by means pulling out the roots. Destructive harvesting by root pulling should account for concern for the plant's sustainability (Farooquee et al. 2004; Kala et al. 2004; Ghimire et al. 2005). Since the natural habitats of $E$. longifolia Jack are found only in certain regions of Indonesia (Sumatra and Kalimantan), it brings about the concern for its extinction. Therefore, E. longifolia Jack requires conservation efforts and silviculture technique to maintain the existence. Moreover, in 2001, Malaysia has declared $E$. longifolia Jack as scarce plant with "indeterminate" status (Rifai 1992). Zuhud and Haryanto (1991) stated that E. 
longifolia Jack is one of 41 medicinal plants which shoud be considered as main priority in research, breeding, development, and utilization.

Currently, there are no national and local regulations covering the management and protection of E. longifolia Jack. Though E. longifolia Jack has economic value, there is no quota regulating its trade. Furthermore, there is a scarcity of research related to its habitat preferences. Therefore, to achieve sustainable utilization, assessments on E. longifolia Jack's habitat preferences, distribution pattern, and root weight estimation are required to determine the sustainable harvesting quota. This research had the objectives to assess the habitat preferences, distribution pattern, and estimation of root weight per hectare of E. longifolia Jack to determine the correct management and sustainable harvesting quota.

\section{Methods}

The research was conducted in the Protected Forest of Ambawang-Pemancingan Mountain in Kubu Raya District, West Kalimantan Province. The protected forest status was based on the Minister of Forestry Decree No. 121/KptsII/2003, covering a total area of $3.370 \mathrm{ha}$. It is positioned on $\mathrm{S} 0^{\circ} 22^{\prime} 1^{\prime \prime}-\mathrm{E} 1^{\circ} 0916^{\prime} 58^{\prime \prime}$. It has an elevation that reached 410 $\mathrm{m}$ asl and slope of $5.35 \%$. The area comprised of various land and vegetation types. It is surrounded by large river, close to the coast and characterized by hilly topography. River banks are the habitats for mangrove and Nypa frutica. Furthermore, sequentially the arrangement of the area of transmigration settlement and agricultural land, oil palm plantation, and hills forest area.

Data collection to assess the potential of E. longifolia Jack was carried out using line plot sampling method, consisted of 5 lines and divided into plots of sized $20 \times 20$ meter. An observation plot of 1 ha was assumed to be able to describe the population condition and the potential root weight. Data recorded in each plot consisted of: total number of individual plant, height, stem diameter, and habitat conditions (temperature, humidity, and light intensity).
Data analysis Variables used to estimate the potential of $E$. longifolia Jack were root weight as dependent variable, and diameter and height as independent variables. These variables are then inputted into the following equations as shown in Equation [1], Equation [2], Equation [3], and Equation [4].

$Y=\mathrm{a}+\mathrm{b} D$

$Y=\mathrm{a}+\mathrm{b} T$

$Y=\mathrm{a} D^{\mathrm{b}}$

$Y=\mathrm{a} T^{\mathrm{b}}$

Note:

$Y=$ root weight $(\mathrm{kg})$

$D=$ stem diameter $(\mathrm{cm})$

$T=$ tree heigh $(\mathrm{m})$

Based on the Equation [1], Equation [2], Equation [3], Equation [4], and data analysis, correlation and proper equation could be obtained. The proper equation was determined from the highest determination coefficient $\left(R^{2}\right)$.

Distribution pattern Morrisita method was used to assess the distribution pattern of E. longifolia Jack. Morissita standard has an interval value from -1.0-1.0 with the limit of confidence interval of 0.5 and 0.5 therefore with Ip value, plant distribution would be obtained, where:

$\mathrm{Ip}=0$, means random distribution pattern

Ip $>0$, means clumped distribution pattern

Ip $<0$, means uniform distribution pattern

\section{Results and Discussion}

Habitat condition of $\boldsymbol{E}$. longifolia Jack E. longifolia Jack has a wide range of topographic distribution. Based on the physical condition in each plot, in general E. longifolia Jack was found at elevation between 5-410 $\mathrm{m}$ asl, where it tent to increase with elevation (Figure 1). Whereas based on collection material found in Herbarium Bogoriense, E. longifolia Jack can be found at elevations of 0-700 $\mathrm{m}$ asl.

Elevation is related to the distribution of climate factors

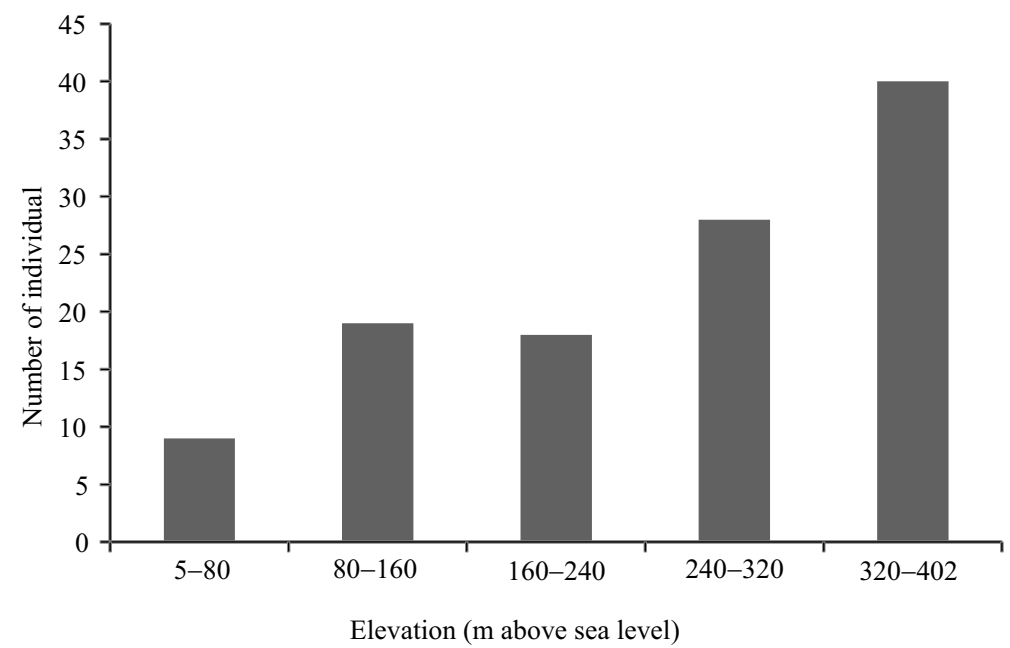

Figure 1 Population distribution of E. longifolia Jack based on elevation (meter above sea level). 
such as temperature, rainfall, humidity, and sunlight intensity. All these factors affect the ecosystem type distribution and hence affect plants' distribution (Ewusie 1990). The ecological parameters observed in the field that corresponded to its elevation were: daily average temperature of $25.6{ }^{\circ} \mathrm{C}$, daily average relative humidity of $88.4 \%$, and light intensity of $0.9 \mathrm{klx}$. These results were similar to those of Ginting (2010) in Medan who obtained daily average temperature of $23.7{ }^{\circ} \mathrm{C}$, daily average relative humidity of $90.8 \%$, and light intensity of $1.136 \mathrm{klx}$. Elevation was found to be inversely correlated with temperature and light intensity and positively correlated with relative humidity. This confirmed with Handoko (1993) who explains that lower humidity corresponds to lower temperature and vice versa. The higher the site, the lower the temperature and light intensity, which is caused by the less absorbance from the air.

Edaphic type of Protected Forest of AmbawangPemancingan Mountain varies from river banks to hillside and comprised of sandy alluvial, peat and red yellow podsolic soil. Results of the soil chemical properties revealed that the contained N-total, Phosphor $(\mathrm{P})$, and Kalium $(\mathrm{K})$ tent to be higher at depth of $0-30 \mathrm{~cm}$ as compared to depth of 30-60 $\mathrm{cm}$. It is reasonable since the organic matter content in topsoil is larger than that from litter decomposition in topsoil. Soil having a $\mathrm{pH}$ of 4.98 at depth of $0-30 \mathrm{~cm}$ is classified as acid soil, and $\mathrm{pH}$ of 4.31 at depth of $30-60 \mathrm{~cm}$ is classified as very acid soil. Based on $\mathrm{C}$ organic and CEC according to the evaluation criteria of chemical properties, the fertility status of this land is categorized as low. On the contrary, according to Ginting (2010), the nutrient content of the growing site of E. longifolia Jack in Bukit Lawang Forest area is quite high. This indicated that E. longifolia Jack could grow in poor nutrient soil as well as in fertile soil. E. longifolia Jack could survive under lack of soil nutrient but do not prefer inundated soil. E. longifolia Jack was largely found in sloping land or hillside. Table 2 and Table 3 presented the chemical and physical properties of the soil samples analysis.

Analysis of the soil physical properties revealed that soil type of research site was categorized as red yellow podsolic (PMK) with clay to sandy clay texture comprised of $23.36-46.81 \%$ sand, $10.61-16.16 \%$ ash, and $37.43-67.03 \%$ clay. Meanwhile, soil structure has formed granular aggregates with size of $2.25-4.14 \mathrm{~mm}$ and moderate aggregates stability with granule and crumbs size classes.

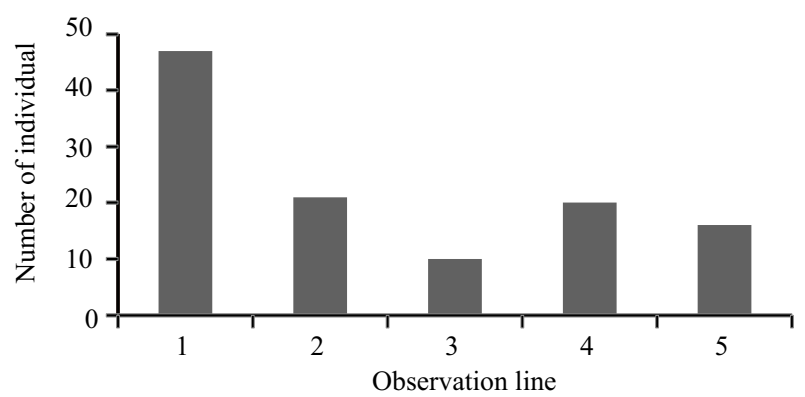

Figure 2 Population of E. longifolia Jack found along the observation lines.
Analysis of the soil physical properties is presented in Table 4.

The acid soil characteristics with sandy clay texture matched the botanic data of pasak bumi in Herbarium Bogoriense, that E. longifolia Jack preferred acid soil and siltsilica (Rifai 1975). It is also similar with results of Ginting (2010) in Bukit Lawang Forest that soil components of $E$. longifolia Jack consisted of sand, ash and clay. Since the bulk density is about $0.91-1.02 \mathrm{~g} \mathrm{~cm}^{-3}$ (standard of bulk density $1.1-1.6 \mathrm{~g} \mathrm{~cm}^{-3}$ ), it is easier for plant roots and water to penetrate into soil layer and improved the soil for water and air fixation (Hardjowigeno 2007). Such soil condition enabled the taproots of E. longifolia Jack to perpendicularly penetrate into the soil layers.

Population condition of $\boldsymbol{E}$. longifolia Jack According to Primack (1998), a stable population usually has specific age distribution comprised of young, mature, and old individuals. Very often, at certain class age if individuals, mainly young individual was not found or found in a very small number, showed a decreased in population. Inversely, seedlings and individuals found in large numbers suggested a stable condition and increase in population.

Based on data gathered from the 25 plots samples of $20 \times$ $20 \mathrm{~m}$ (1 ha), E. longifolia Jack population were found almost in every plot (23 plots) with 114 individuals. Only 2 plots had no E. longifolia Jack, i.e., in line 1 plot 1 and in line 2 plot 4 due to the rocky condition and domination by bamboo and rattan. Population of $E$. longifolia Jack within observation lines is presented in Figure 2. Based on the structure of growth class in all plot lines, the total number of seedlings found was 71 individuals $(62.28 \%)$, saplings 42 individuals (36.84\%), and poles only 1 individual $(0.87 \%)$. Such $E$. longifolia Jack growth structure was ecologically normal since in natural forest the normal vegetation structure is indicated by inverted " $J$ " curve. It means that in sequence, the number of seedlings should be greater than saplings, the number of saplings should be greater than poles, and the number of poles should be greater than trees. Growth structure of E. longifolia Jack population is presented in Figure 3.

The small numbers of individuals in sapling and pole stages having diameter class of $10-20 \mathrm{~cm}$ were caused by the high rate of exploitation of E. longifolia Jack roots. Over exploitation has led to scarcity since it caused the death of

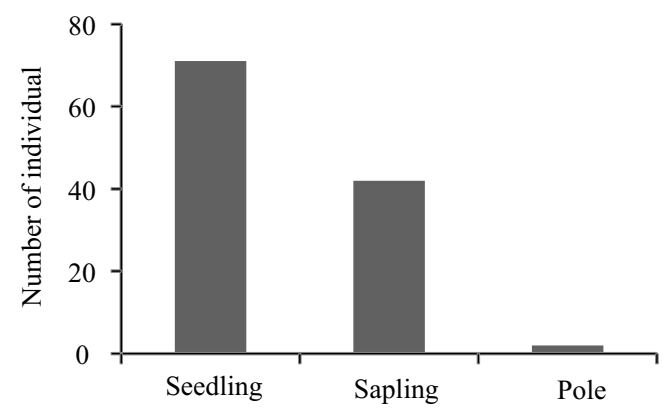

Figure 3 Growth class structure. 
Table 1 Average habitat microclimate of E. longifolia Jack based on elevation during observation periods: morning, noon, and afternoon

\begin{tabular}{cccccccccc}
\hline \multirow{2}{*}{$\begin{array}{c}\text { Elevation } \\
(\mathrm{m} \text { asl) }\end{array}$} & \multicolumn{3}{c}{ Temperature $\left({ }^{\circ} \mathrm{C}\right)$} & \multicolumn{3}{c}{ RH $(\%)$} & \multicolumn{3}{c}{ Light $(\mathrm{klx})$} \\
\cline { 2 - 10 }$y$ & Morning & Noon & Afternoon & Morning & Noon & Afternoon & Morning & Noon & Afternoon \\
\hline $5-80$ & 22 & 29 & 27 & 59 & 80 & 66 & 0.93 & 1.56 & 1.06 \\
$80-160$ & 24 & 29 & 26 & 60 & 87 & 70 & 0.91 & 1.26 & 0.87 \\
$160-240$ & 23 & 28 & 26 & 57 & 90 & 72 & 0.85 & 1.41 & 0.96 \\
$240-320$ & 24 & 26 & 25 & 68 & 95 & 73 & 0.52 & 0.86 & 0.63 \\
$320-402$ & 24 & 27 & 25 & 68 & 90 & 69 & 0.49 & 0.71 & 0.53 \\
\hline Average & 23.4 & 27.8 & 25.8 & 62.4 & 88.4 & 70 & 0.74 & 1.16 & 0.81 \\
\hline
\end{tabular}

Observation time: morning (07.00-09.00); noon(12.00-14.00); afternoon (15.00-16.00)

Table 2 Soil chemical properties in protected forest of Ambawang-Pemancingan Mountain

\begin{tabular}{lccccccc}
\hline \multicolumn{1}{c}{ Samples } & $\begin{array}{c}\mathrm{N} \\
(\%)\end{array}$ & $\begin{array}{c}\mathrm{P} \\
\left(\mathrm{mgL}^{-1}\right)\end{array}$ & $\begin{array}{c}\mathrm{K} \\
\left(\mathrm{me} 100 \mathrm{~g}^{-1}\right)\end{array}$ & $\begin{array}{c}\mathrm{K} \\
\left(\mathrm{me}^{\left.100 \mathrm{~g}^{-1}\right)}\right.\end{array}$ & $\begin{array}{c}\mathrm{PH} \\
\left(\mathrm{H}_{2} \mathrm{O}\right)\end{array}$ & $\begin{array}{c}\mathrm{C} \\
(\%)\end{array}$ & $\begin{array}{c}\mathrm{KTK} \\
\left(\mathrm{me}^{100 \mathrm{~g}^{-1}}\right)\end{array}$ \\
\hline $0-30$ & 0.21 & 4.47 & 0.11 & 4.98 & 4.98 & 1.81 & 12.79 \\
$30-60$ & 0.18 & 0.87 & 0.08 & 4.31 & 4.31 & 0.97 & 12.73 \\
\hline
\end{tabular}

$0-30$ : soil samples taken from the depth of $0-30 \mathrm{~cm} ; 30-60$ : soil samples taken from the depth of $30-60 \mathrm{~cm}$

Table 3 Guidance for analysis result of soil fertility

\begin{tabular}{|c|c|c|c|c|c|c|}
\hline \multirow{2}{*}{ Parameter } & \multirow{2}{*}{ Unit } & \multicolumn{5}{|c|}{ Fertility } \\
\hline & & Very low & Low & Moderate & High & Very high \\
\hline C-Organic & $\%$ & $<1.0$ & $1-2$ & $2-3$ & $3-5$ & $>5$ \\
\hline $\mathrm{N}$ total & $\%$ & $<0.1$ & $0.1-0.2$ & $0.2-0.5$ & $0.5-0.75$ & $>0.75$ \\
\hline $\mathrm{C} / \mathrm{N}$ ratio & & $<5$ & $5-10$ & $11-15$ & $16-25$ & $>25$ \\
\hline$P$ available & $\mathrm{mgL}^{-1}$ & $<10$ & $10-15$ & $16-25$ & $26-35$ & $>35$ \\
\hline $\mathrm{Ca}$ & meq100 $\mathrm{g}^{-1}$ & $<2.0$ & $2.0-5.9$ & $6.0-10.9$ & $11.0-20.0$ & $>20.0$ \\
\hline $\mathrm{Mg}$ & meq100 $\mathrm{g}^{-1}$ & $<0.4$ & $0.4-1.0$ & $1.1-2.0$ & $2.1-8.0$ & $>8.0$ \\
\hline $\mathrm{K}$ & meq100 $\mathrm{g}^{-1}$ & $<0.1$ & $0.1-0.3$ & $0.4-0.5$ & $0.6-1.0$ & $>1.0$ \\
\hline $\mathrm{Na}$ & meq $100 \mathrm{~g}^{-1}$ & $<0.1$ & $0.1-0.3$ & $0.4-0.7$ & $0.8-1.0$ & $>1.0$ \\
\hline CEC & meq100 $\mathrm{g}^{-1}$ & $<5.0$ & $5.1-16.0$ & $16.1-24.0$ & $24.1-40.0$ & $>40.0$ \\
\hline Base saturation & $\%$ & $<10.0$ & $10.1-35.0$ & $35.1-50.0$ & $50.1-70.0$ & $>70.0$ \\
\hline $\mathrm{pH} \mathrm{H} \mathrm{H}_{2} \mathrm{O}$ & very acid & acid & quite acid & neutral & quite alkaline & alkaline \\
\hline & $<4.5$ & $4.5-5.5$ & $5.6-6.5$ & $6.6-7.5$ & $7.5-8.5$ & $>8.5$ \\
\hline
\end{tabular}

Source: Biotrop Laboratory, Bogor

$\mathrm{CEC}=$ Cation exchange capacity $(\mathrm{KTK})$

parental trees. According to Hussein et al. (2005), the propagation of E. longifolia Jack has so far relies on wild seed. Meanwhile, as recalcitrant plant, the viability tent to be low and took a long time to germinate since zygotic embryo is immature during dispersion. Seed with undeveloped embryo during dispersion would not germinate in normal condition and hence, would be categorized as dormant. Related to the morphology stage of immature embryo, this phenomenon is often classified as morphologically dormant.

Copeland and McDonald (1995) suggest that recalcitrant seed has short life term period and it difficult to store due high to water content that lead to microbial contamination, easily degraded and lead to death. Moreover, the obtained values of the microclimate measurements were: temperature of 23.4-27.8 ${ }^{\circ} \mathrm{C}$, relative humidity of $64-88.4 \%$, and light intensity ofs $0.74-1.16 \mathrm{klx}$. These measurements indicated that biologically the forest condition has medium temperature, high enough humidity, and quite low light intensity. All these conditions had prolonged seed dormancy process in natural forest. In addition, the seeds had been attacked by fungi and rot hence inhibited the seedling growth on forest floor.

Based on class diameter and height structure of $E$. longifolia Jack, there was a tendency that the bigger the diameter and height class, the lower the population of $E$. longifolia Jack. Population of E. longifolia Jack was higher in diameter class of $<1 \mathrm{~cm}$, with 62 individuals. For diameter above $5 \mathrm{~cm}$ only 1 individual was found with class diameter of $9 \mathrm{~cm}$ located at the peak of the mountain. Similarly, the highest population was found in class diameter of $1-2 \mathrm{~m}$. The low number of population above $5 \mathrm{~cm}$ and height more than 3 $\mathrm{m}$ occurred due to the high rate of E. longifolia Jack root exploitation in class diameter of 10-20 cm. Histograms of $E$. longifolia Jack based on diameter and height class are presented in Figure 4 and Figure 5. 
Estimation of root potential $E$. longifolia Jack is a plant with all parts functioned for medicines (root, stem, root bark, and leaf), with the most commonly used part is the root. Until now, the supplies for E. longifolia Jack were derived from natural forest instead of plantations by means of pulling out the roots. Therefore, to identify the root potential of $E$. longifolia Jack in kilogram per hectare unit, estimation using correlation test of 5 samples of E. longifolia Jack representing diameter and height classes were used. Considering the highest determination coefficient $\left(\mathrm{R}^{2}\right), E$. longifolia Jack root weight can be estimated using exponential equation with independent variable the tree height using $Y=21.99 T^{0,010}$ with determination coefficient of 0.97. It means that the independent variable (tree height) could explain its dependent variable $(E$. longifolia Jack root weight) as $97 \%$. In other words, tree height is responsive to root weight changes. Graphic exponential equation of root weight estimation of E. longifolia Jack with stem height as

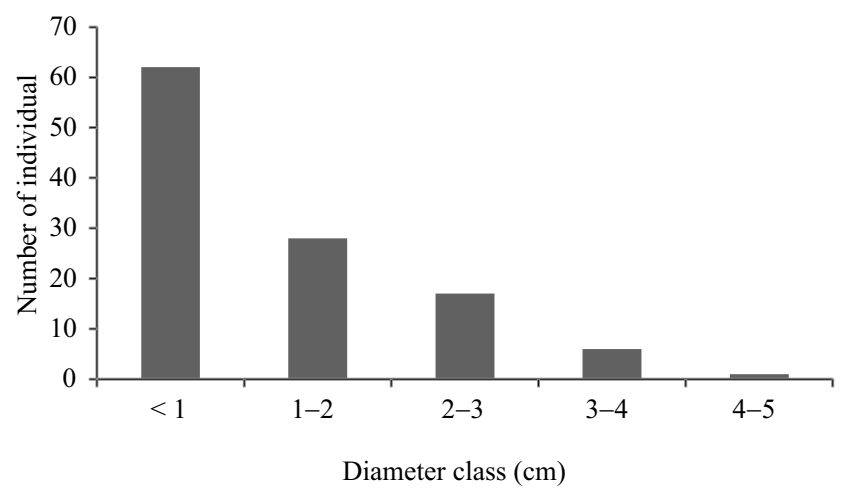

Figure 4 Diameter class structure of E. longifolia Jack. population. variable is presented in Figure 6.

The selected equation could be used to estimate the root potential harvested in particular areas. For instance, based on an inventory of $E$. longifolia Jack with tree height of less than $3 \mathrm{~m}$ is $85 \%$ from the numbers of E. longifolia Jack found in research plot, then the harvested root is $15 \%$ from the total. After input the height variable into the selected estimation model, the minimum potential of root weight can be obtained. The amount of E. longifolia Jack harvested in 1 ha is $0.33 \mathrm{~kg}$. The root weight potential that could be harvested was relatively in small numbers due to the structure composition of tree height in a range of $1-3 \mathrm{~m}$. This condition indicated that there were more seedlings and saplings found in the observation plots that affected the available quantity of E. longifolia Jack to be harvested. Physiologically, tree height growth is a process of primary growth due to the process of meristem cell activities that caused prolonged stem and root. Primary growth occurred because of growth

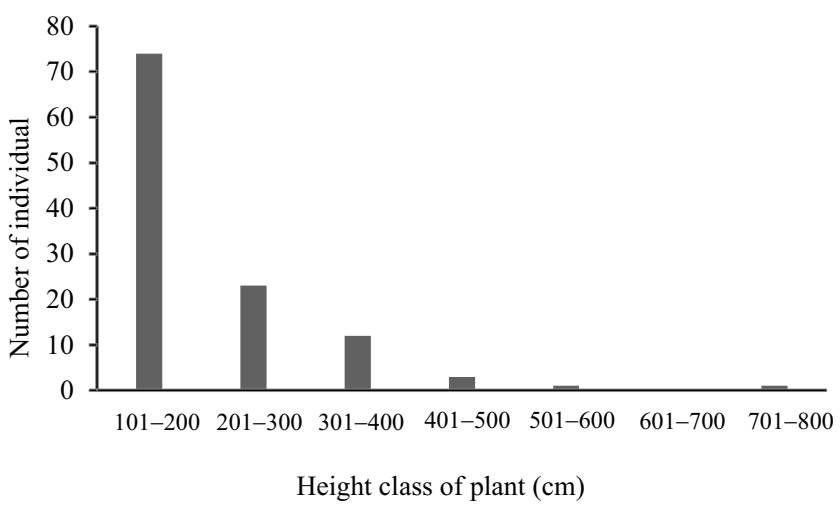

Figure 5 Height class structure.

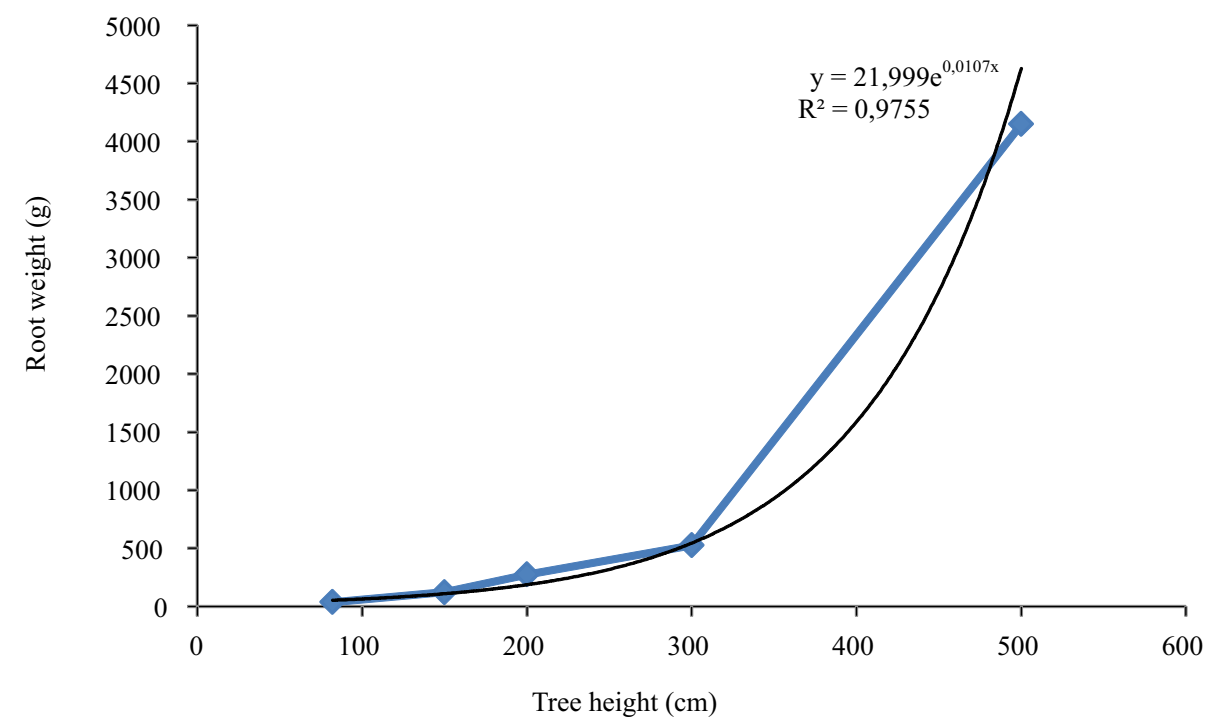

Figure 6 Exponential equation of root weight estimation of $E$. longifolia Jack with stem height variable. 
point namely stem and root tip. Meanwhile, for diameter growth, the cambium activity was responsible to enlarge the stem. Primary and secondary growth can occur simultaneously at the same time (Campbell et al. 2000). However, based on the analysis result of site area condition, E. longifolia Jack could survive under poor nutrient level of red yellow podsolic with very acid soil $\mathrm{pH}$. They were frequently found in low slope or hillsides. These conditions signified that due to nutrient and water shortages, cell mitosis in secondary growth has decreased. Inversely, cell mitosis was more active as the plant adapted to the environment. The root grew deeper to absorb nutrient and water, causing the plants to increase in height in search for sunlight.

Van Noordwijk and Purnomosidhi (1995) report that trees with vertical roots that were well-developed and have less lateral root, generally had slow initial growth. Murniati (2009) also reports that in fertile soil, tree root could easily absorb nutrient and water. In that case, it is not important to pile up on or allocate food stock (photosynthesis result) for new root growth. Most of food stocks were accumulated in the upper part of the soil, so that shoot-root ratio became higher. In the opposite scenario, it was estimated that this occurred on trees grew or planted in high elevation area (hillside or hilltop).

This justified the reason that root is the inseparable part of the plant and played an important role as well as the upper parts of the plant. The root functioned to absorb water and nutrients, while the stem functioned to distribute and utilize it during growth period. Besides, according to the concept of morphological balance or morphogenetic balance stated by Hellriegel in 1883 (de Willingen \& van Noordwijk 1987) it is necessary to maximize root growth in order to gain better growth of upper plant parts.

Distribution pattern The distribution of E. longifolia Jack was found in clumped pattern. E. longifolia Jack was commonly found close to the mother tree. Regardless of the effect of environmental and competition factors, this result was relevant to the conclusion of Barbour et al. (1987) that the distribution pattern of plant species tend to clumped since the seed fallen closed to their parents. According to Ewusie (1986), big and small plants are both competing against each other for light, mineral or space especially for habitat and also for water which was probably limited. The most critical was the competition among individuals of the same species due to common basic needs. Since E. longifolia Jack is growing closed to each other, the competition occurred among seedling individuals. Only small parts of the seedling could survive in adaptation. Individuals able to survive could grow to higher growth stage. This phenomenon explained the reason for the weaker grouping stage of $E$. longifolia Jack as the growth stage increased. Distribution pattern of $E$. longifolia Jack within the 5 observation in the Protected Forest of Ambawang-Pemancingan Mountain is given in

Table 4 Soil physical properties in protected forest of Ambawang-Pemancingan Mountain

\begin{tabular}{|c|c|c|}
\hline \multirow{2}{*}{ Parameter analysis } & \multicolumn{2}{|c|}{ Result of soil sample analysis } \\
\hline & $0-30$ & $0-60$ \\
\hline \multicolumn{3}{|l|}{ Structure } \\
\hline - $\quad$ Shape of aggregates & Granular & Granular \\
\hline - $\quad$ Size $(\mathrm{mm})$ & 4.14 & 2.25 \\
\hline - $\quad$ Aggregates stability (\%) & Moderate $(54.09 \%)$ & Moderate $(59.09 \%)$ \\
\hline - $\quad$ Size class & Granule and crumb & Granule and crumb \\
\hline \multicolumn{3}{|l|}{ Texture (\%) } \\
\hline - $\quad$ Sand & 23.36 & 46.81 \\
\hline - $\quad$ Ash & 10.61 & 16.16 \\
\hline - $\quad$ Clay & 67.73 & 37.43 \\
\hline Water content $(\%)$ & 46.01 & 25.92 \\
\hline Bulk density $\left(\mathrm{gr} \mathrm{cm}^{-3}\right)$ & 0.91 & 1.02 \\
\hline Particle density $\left(\mathrm{gr} \mathrm{ml}^{-1}\right)$ & 2.58 & 2.61 \\
\hline Porosity (\%) & 64.73 & 60.92 \\
\hline
\end{tabular}

Table 5 Distribution pattern of E. longifolia Jack in protected forest of Ambawang Pemancingan Mountain

\begin{tabular}{cccccc}
\hline Line & $\mathrm{I}_{\delta}$ & $\mathrm{Mu}$ & $\mathrm{Mc}$ & $\mathrm{Ip}$ & Distribution \\
\hline 1 & 1.547 & 2.849 & -0.098 & 0 & Random \\
2 & 0.647 & 1.772 & 0.561 & 0.402 & Clumped \\
3 & 0.444 & 1.458 & -0.064 & 0 & Random \\
4 & 0.547 & 2.281 & 0.150 & 0.248 & Clumped \\
5 & 0.333 & 2.481 & 0.350 & 0.513 & Clumped \\
\hline
\end{tabular}

$\mathrm{I}_{\delta}$ : Morrissita Distribution Index; Mu: Uniformity Index; Mc: Clumped Index; Ip: Morissita 
Table 5 .

\section{Conclusion}

The research found as many as 114 individuals E. longifolia Jack in the study site, with the highest population found in seedling stage comprised of 71 individuals $(62.28 \%)$. The highest density was found within the elevation range of 320-402 $\mathrm{m}$ above sea level with 40 individuals, with distribution found in clumped pattern. The habitat conditions were characterized by average temperature of $25.6{ }^{\circ} \mathrm{C}$, daily average relative humidity of $73.6 \%$, light intensity of $0.9 \mathrm{klx}$, and red-yellow podsolic soil with clay to sandy clay texture. The selected estimator model for E. longifolia Jack root weight used exponential equation with stem height as independent variable with the equation of $Y=21.99 T^{0,0100}$ and determination coefficient of 0.97 . After height variable was added, the potential of E. longifolia Jack minimum root weight available for harvesting per hectare was found to be $0.33 \mathrm{~kg}$. The potential root weight available for harvesting was relatively low since the tree height structure was dominated by seedling and sapling growth stages.

\section{Recommendation}

In order to reduce the exploitation of E. longifolia Jack, sustainable harvesting quota should be determined and silvicultural technique for E. longifolia Jack should be developed.

\section{References}

Ang HH, Lee KL, Kiyoshi M. 2004. Sexual arousal in sexually sluggish old male rats after oral administration of Eurycoma longifolia Jack. Journal of Basic and Clinical Physiology and Pharmacology 15:303-309. http://dx.doi.org/10.1515/JBCPP.2004.15.3-4.303.

Ang HH, Ngai TH, Tan TH. 2003. Effects of Eurycoma longifolia Jack on sexual qualities in middle aged male rats. Journal Phytomedicine10:590-593. http://dx.doi.org/10.1078/094471103322331881.

Chan KL, Choo Cy, Abdullah NR. 2005. Semisynthetic 15O-acyl- and 1,15-di-O-acyleurycomanones from Eurycoma longifolia as potential antimalarials. Journal Planta Medica 71(10):967-969. http://dx.doi.org/10. 1055/s-2005-864188.

Barbour GM, JK Busk, WD Pitts. 1987. Terrestrial Plant Ecology. New York: The Benyamin/Cummings Publishing Company, Inc.

Campbell NA, JB Reece, LG Mitchell. 2000. Biology $5^{\text {th }}$ Edition Part 2. Manalu W, translator. Translated from: Biology Fifth Edition. Jakarta : Erlangga Publisher.

Copeland LO, MB McDonald. 1995. Principles of Seed Science and Technology. New York: Chapman and Hall Press.

De Willingen $\mathrm{P}$ and $\mathrm{M}$ van Noordwijk. 1987. Roots, plant production, and nutrien efficiency. Phd thesis.
Wageningen Agricultural University, Wageningen. The Netherlands.

Effendy NM, Norazlina M, Norliza M, Isa NM, Ahmad NS. 2012. Eurycoma longifolia: Medicinal plant in the prevention and treatment of male osteoporosis due to androgen deficiency. Evidence-Based Complementary and Alternative Medicine 2012: (1-9). http://dx.doi.org/ $10.1155 / 2012 / 125761$

Ewusie JP. 1986. Introduction to Tropical Ecology. Bandung: Institute of Technology Bandung Press.

Farouk AE, Benafri A. 2007. Antibacterial activity of Eurycoma longifolia Jack. A Malaysian medicinal plant. Saudi Medical Journal 28:1422-1424.

Farooquee NA, Majila BS, Kala CP. 2004. Indegenous knowledge systems and sustainable management of natural resources in a high altitude society in Kumaun Himalaya, India. Journal of Human Ecology 16:33-42.

Ghimire SK, McKey D, Aerumeeruddy-Thomas Y. 2005. Heterogenity in etnoecological knowledge and management of medicinal plants in the Himalayas of Nepal: Implication for conservation. Ecology and Society $9: 36$

Ginting BRA. 2010. Ecological assessment of pasak bumi (Eurycoma longifolia Jack) and its utilization by local community around the Bukit Lawang Forest [thesis]. Medan: University of North Sumatera.

Handoko 1993. Basic Climatology. Jakarta: PT Dunia Pustaka Jaya.

Hardjowigeno. 2007. Soil Science. Jakarta: Pustaka Utama Publisher.

Heyne K. 1950. Beneficial plants of Indonesia. Translated in 1987. Jakarta: Sarana Wana Jaya foundation, Forestry and Development Agency Ministry of Forestry.

Hussein S, Ibrahim R, Kiong ALP, Fadzilah NM, Daud SK. 2005. Multiple shoot formation of important tropical mediclinal plant, Eurycoma longifolia Jack. Journal of Biotechnology 22:349-351.

Kala CP, Farooquee NA, Dhar U. 2004. Prioritization of medicinal plants on the basis of avalaible knowledge, existing practices and use value status in Uttaranchal, India. Biodiversity and Conservation 13:453-469. http://dx.doi.org/10.1023/B:BIOC.0000006511.67354.7 f.

Kuo PC, Shi LS, Damu AG. 2003. Cytotoxic and antimalarial beta-carboline alkaloids from the roots of Eurycoma longifolia. Journal of Natural Products 66:1324-1327. http://dx.doi.org/10.1021/np030277n.

Kuo PC, Damu AG, Lee KH, Wu TS. 2004. Cytotoxic and antimalarial constituents from the roots of Eurycoma 
longifolia. Bioorganic and Medicinal Chemistry 12:537-544. http://dx.doi.org/10.1016/j.bmc.2003. 11.017 .

Nurhanan MY, Azimahtol HLP, Mohd IA, Shukri MA. 2005. Cytotoxic effects of the root extracts of Eurycoma Longifolia Jack. Journal of Phytoteraphy Research. 19(11): 994-996. http://dx.doi.org/10.1002/ptr.1759.

Odum EP. 1971. Fundamentals of Ecology. Second edition. Philadelphia: WB Saunders Company.

Primack RB. 1998. Conservation Biology. Jakarta: Yayasan Obor Indonesia.

Rifai MA 1975. Botanic Data of Pasak Bumi Plant in Symposium of Medicinal Plants Research I. Bogor: Department of Pharmacology FKH-IPB.

Rifai MA. 1992. Eurycoma longifolia Jack. In: Rifai et al., editors. Thirty Scarce Plants of Indonesia Floribunda $2: 1-28$.

Mardisiswojo S, Harsono. 1968. Cabe Puyang chilly of Ancestors Heritage Moyang. Book I. Jakarta: PT Karya Wreda Publisher.
Murniati. 2009. Tree arhitecture, root distribution, and estimation of tree biomass in an agroforestry system. Journal of Forest Research and Nature Conservation 7(2):103-116.

Sumatra Pasak Bumi. 2013. Tongkat ali extract and tongkat ali chipped root. www.tongkatali.org/index.htm. [13 March 2014].

Tee TT, Cheah YH, Hawariah LP. 2007. A fraction from Eurycoma longifolia Jack extract, induces apoptosis via a caspase-9-independent manner in MCF-7 cells. Anticancer Research 27:3425-3430.

Van Noordwijk M, Purnomosidhi P. 1995. Root architecture in relation to tree-soil-crop interactions and shoot pruning in agroforestry. Agroforestry Systems 30:161-173.

Zuhud EAM, Haryanto. 1991. Preservation of medicinal plants utilization from Indonesia. In: Zuhud EAM, Haryanto, Editors. In Proceeding of Preservation of Medicinal Plants Utilization from Indonesian Tropical Forest. Bogor: Department of Forest Resources Conservation IPB in cooperation with The Indonesia Wildlife Fund. 